\title{
結核患者における末梢血および肉芽腫組織に扔ける 樹状細胞の検討
}

\author{
上平 和 孝 \\ (内科学第一講座)

\section{Dendritic Cells are Decreased in Blood and Accumulated in Granuloma in Tuberculosis}

\author{
Kazutaka UEHIRA
}

\begin{abstract}
要 約
結核に対する免疫は自然免疫と獲得免疫で構成される，我々は，多様な免疫応答を誘導するとされる樹状細胞 (dendritic cells; DC) の動態を，結核患者において解析した，DCは骨䯣幹細胞から，異なる分化経路を経て，それぞ れの組織，器官に分布する．そしてDC は分化経路および属性から，大きくミエロイド系とリンバ球系の 2 つに分類 される. 末梢血中には，表面抗原のパターンにより少なくとも 3 つの亜群が存在することを当教室より報告している [Fraction $1 \mathrm{DC} ; \mathrm{CD}^{+} / \mathrm{CD}^{+} \mathrm{c}^{+}$, Fraction $2 \mathrm{DC} ; \mathrm{CD1a} / \mathrm{CD} 11 \mathrm{c}^{+}$, Fraction $\left.3 \mathrm{DC} ; \mathrm{CD1a} / \mathrm{CD} 11 \mathrm{c}\right]$. 前 2 者は, いわゆる myeloid DC であり, fraction 3 は lymphoid DC (plasmacytoid DC) である.

21 名の末梢血 DC の解析では, 結核患者の末梢血 DC が健常者に比較して有意に減少しており，さらに亜群解析の結 果，この隇少は Fraction 1 及び Fraction 2 DC の隇少に起因することが明らかとなった. 21 名の結核組織の免疫染色で

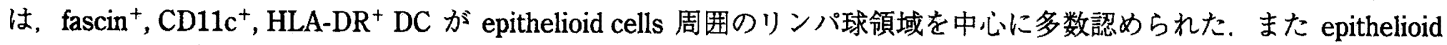
cells 周囲リンパ球領域では IFN $\gamma$ 産生細胞が多数認められ, Th1 偏向を示していることが明かとなった.

Bacillus calmette Guerin（BCG）存在下あるいは非存在下で，ミエロイド系 DCである Fraction 1 及び Fraction 2 DC (CD11c DC) とリンパ球系 DC である Fraction $3 \mathrm{DC}(\mathrm{CD11c} \mathrm{DC})$ のそれぞれを autologous naive Th と共培盖するこ とにより，DCの Th1 あるいは Th2への誘導能を検討した結果, $\mathrm{CD} 11 \mathrm{c}^{+} \mathrm{DC}, \mathrm{CD} 11 \mathrm{c}-\mathrm{DC}$ はともに BCG 非存在下に比 ベ BCG を加えた共培養系においてより強く Th1 が誘道された。

これらの結果から，結核の病態において末梢血 DC（主に CD11 $\mathrm{c}^{+} \mathrm{DC}$ ) が結核組織に動員され，抗原を取り込んた 後成熟し, 所属りンパ節で naive Thを Th1 に誘導していることが示唆された.
\end{abstract}

目的

Mycobacterium tuberculosis（M.tb）は結核症の 原因菌であり，結核症は現在全世界で年間約 800 万人が発症し， 300 万人の死者を出しており，最 も多い感染症死亡の原因の 1 つである ${ }^{1)}$. 結核感 染における防御免疫は自然免疫と獲得免疫があ る.結核において自然免疫の主役はマクロファー ジであり，一方獲得免疫は $\mathrm{T}$ 細胞による抗原特異 的な応答である ${ }^{2,3)}$. これまで結核に対する防御免 疫はTh 1の誘導が重要であることが報告されてい る。しかしながら結核患者においてどのように Th1 誘尊がなされているかは明らかでない.

樹状細胞 (dendritic cells; DC) は生体に広く分 布し, 強力な抗原提示細胞 (Antigen-presenting cells; APC) であり, naive T cells を primingする能 力を有しており, Th balance の誘導に重要な役割 を担っている. DC は骨髄幹細胞から, 異なる分 化経路を経て，それぞれの組織，器官に分布する. DCは分化経路および属性から，大きくミエロイド 系とリンパ球系の 2 つに分類される，また，機能 的に DC1 および DC2 と分類することが近年提唱 されており，DC1 は interleukin (IL)-12を介して naive Th細胞を Th1 細胞に誘導し, DC2 は Th2 細胞 に誘導するとされる ${ }^{4)}$. 種々のサイトカイン存在 下では，ミエロイド系 DC とリンパ球系 DC が有 する Th1 誘導能あるいはTh2 誘導能に影響を与え る ${ }^{5)}$ ささらに各 DC 悪群はその成熟度や抗原によ り異なる反応を誘遒する ${ }^{6,7)}$. 
このように DC には，2つの細胞系列が存在し それぞれ異なる機能を有し, 免疫システムの中枢 に位置し，免疫反応において司令塔の役割を担っ ている，以上の事実から DC は，深く感染症に関 与しており，結核免疫においても重要な役割を果 たしていることが推測される。しかしながら結核 菌抗原の DCに及ほす in vitroでの研究報告はある が 8-10)，in vivo における報告はほとんどなく，結 核における DC の本質的な役割については不明で ある。

末梢血中には，表面抗原のパターンにより少な くとも 3 つの亜群が存在することを当教室より報 告している [Fraction $1 \mathrm{DC} ; \mathrm{CD}^{+} / \mathrm{CD}^{+} 1 \mathrm{c}^{+}$, Fraction 2 DC; CD1a $/ \mathrm{CD}_{11 c^{+}}$, Fraction $3 \mathrm{DC}$; CD1a $\left./ \mathrm{CD}_{11 \mathrm{c}}^{-}\right]^{11)}$. Fraction 1 および Fraction 2 DC はミエ ロイド系 DC で Fraction 3 DC はリンパ球系 DCで ある. Fraction 3 DC は plasmacytoid DC の precursorであり血中のinterferon- $\alpha$-producing cells (IPC) としても認識されている ${ }^{12)}$. これら末梢血 (peripheral blood: PB) DC は未成熟段階にあり，各 組織に配置される以前の未熟 DC あるいは DC precursor であると考えられている，健常者では PBDC は steady-state 'sentinel' DC の主な供給源で あると考えられている。一方感染症などの緊急時 にはPBDC は末梢血中から感染組織に 'danger’ signalsにより動員され免疫応答を発動するものと 考えられる. 我々は primary Sjögren's syndromeに 扣いて，末梢血から選択的に棰液腺に移動するこ とにより末梢血Fraction 1 DCが減少していること を報告した。この事実から Sjögren's syndromeの 病態生理において DC が本質的に寄与しているこ とが推測される ${ }^{13)}$. われわれはこの研究で, 初発 時の結核患者の末梢血と結核組織（肉芽腫組織） の DC の解析を試みた結果, Fraction 1 および Fraction 2 DC が末梢血から選択的に結核組織に移 動し, 組織での Th 1 偏向をひきおこしていること を証明した。

\section{対象}

インフォームドコンセントを得た抗結核療法前 （未治療）の結核患者 42 名（男性 24 人，女性 18 人, 年齢: $24 \sim 83$ 歳, 中央值 53 歳) を対象とし た（肺結核：24 名, 結核性胸膜炎: 4 名, 結核性 リンパ節炎：6 名, 皮下組織結核：2 名, 肺結核
に結核性胸膜炎あるいは結核性リンパ節炎の合 併 : 6 名)。このうち末梢血 DC の検討において対 象とした患者は, 21 人（男性 14 人，女性 7 人， 年齢： $24 \sim 83$ 歳, 中央値 39 歳) である. 対照 は，年齢・性を一致させた健常人 15 名（男性 9 人, 女性 6 人, 年齢: $25 \sim 78$ 歳, 中央值 34 歳) である，結核組織の免疫染色の対象患者は，患者 数は 21 人（男性 10 人，女性 11 人，年龄： 29 〜 70 歳, 中央值 58 歳) である (肺：9 例, 胸膜： 3 例, リンパ節：7 例及び皮下組織：2 例）である. 結核の診断は 1990年American Lung Association 結 核診断基準を満たすものとした。

\section{方 法}

1) 末梢血 (peripheral blood; PB) DC の単離・解 析

健常者及び患者より得た血液より，単核球分 画を比重遠心法にて分離した後, 抗 CD3 抗体, 抗 CD14 抗体及び抗 CD19 抗体を用いた immunoselectionにより $\mathrm{T}$ 細胞, B 細胞及び単球 を除去した. 更に磁気ビーズ標識抗 CD4 抗体を 用い, positive selectionを行い, CD4+CD3-CD14CD19-の樹状細胞濃縮分画を調整した，この樹 状細胞濃縮分画を抗 CD1a 抗体, 抗 CD11c 抗体, 抗 HLA-DR 抗体，抗成熟分化マーカー (Lineage) 抗体（抗 CD3, CD14, CD15, CD16, CD19, CD56 抗体）で染色し，4-color-cell sorter にて解析, 純化を行った. DC 数 $(\mathrm{ml})$ は FCM の total eventに対する各々の fractionの比率を末梢血単 核球数 $(\mathrm{PBMC} / \mathrm{ml})$ に乗じて算出した。

2) 免疫染色

免疫染色は診断のために採取された結核組織 を用いて行った。

ホルマリン固定・パラフィン包埋の組樴では, 以下の一次抗体を用いた. Fascin は内皮細胞や 扁平上皮細胞等に発現が認められるが, 血液系 の細胞ではEB virus infected $\mathrm{B}$ cells と mature DC に発現が限局していることから, mature DC に 特異的な markerと考えられる.よって anti-fascin $\mathrm{mAb}$, anti-CDla mAb, anti-HLA-DR mAb を用い $\mathrm{DC}$ 同定した. $\mathrm{T}$ 細胞の同定は anti CD4 mAb, anti CD8 mAbを用いた. 凍結標本では, anti-IFNy $\mathrm{mAb}$, anti-IL-4 mAbs, anti-IL-10 mAbs 使用し, Tリンパ球のサイトカイン産生を解析した。 
anti-CD11c mAbを用い, DCのCD11cの発現の有 無を調べた。さらに anti-IFN $\alpha \mathrm{mAb}$ を用い fraction 3 DC の同定した.

3) Mycobacterium bovis Bacillus Calmette and Guérin (BCG) 刺激下での CD11c ${ }^{+}$DC (Fraction 1+2 DC) および CD11c- DC (Fraction $3 \mathrm{DC}$ ) と ナイーブ $\mathrm{T}$ 細胞の autologous 共培養

免疫磁気ビーズ法により健常人の末梢血 $\mathrm{PBMC}$ から $\mathrm{CD}^{+} / \mathrm{CD} 45 \mathrm{RA}{ }^{+}$細胞をナイーブT細 胞として得た. Sortingにより分離したそれぞれ $1 \times 10^{4}$ 個の CD11c $\mathrm{c}^{+} \mathrm{DC}$ およびCD11c DCを BCG (a multiplicity of infection: MOI of 2 to 5) ととも に共培養 $\left(37^{\circ} \mathrm{C}\right.$ で overnight）した. 培養後, $\mathrm{DC}$ 回収した。さらにCD11c+DCおよびCD11c $\mathrm{DC}$ はそれぞれ $5 \times 10^{4}$ 個のナイーブ $\mathrm{T}$ 細胞と autologous共培養を施行した. 7 日目にCD4+ T細 胞を細胞内染色法により処理し IFN $\gamma$ および IL4 産生細胞の比率を検討した.

4) 統計学的処理

すべての統計学的処理は, Stat-view statistical program (Abacus Concepts)を用い Mann-Whitney $\mathrm{U}$ test にて施行した. 同順位補正後の p value （tied $\mathrm{p}$ value）が $5 \%$ 以下のものを有意差ありと した.

結 果

1) 絵 $\mathrm{PBDC}$ および各 Fraction の PBDC の絶対数 結核患者の総PBDCおよび各FractionのPBDC の絶対数を年齢, 性を一致させた健常者のコン
トロールと比較した（図 1）。結核患者では総 PBDC 数が健常者に比較して有意に減少してお り (controls: mean 17,132/ml, range 8,313-32,708/ $\mathrm{ml}$, 結核患者: mean $9,711 / \mathrm{ml}$, range 2,414$27,819 / \mathrm{ml})(\mathrm{p}=0.001)$, さらに亜群解析の結果, この減少は Fraction 1 DC (controls: mean 9,236/ $\mathrm{ml}$, range 4,300-18,496/ml, 結核患者 : mean 4,106/ml, range 352-10,998/ml) 及び Fraction 2 DC (controls: mean 1,639/ml, range 637-3,264/ $\mathrm{ml}$, 結核患者 : mean 648/ml, range 52-1,303/ml) の減少に起因することが明らかとなった (Fraction 1 DC: $p<0.0005$ and Fraction 2 DC: $\mathrm{p}<0.0001$ ) (図 1). Fraction 3 DC は若干の減少を 認めたものの統計学的に有意ではなかった (controls: mean 6,258/ml, rnge 3,061-10,948/ml, 結核患者: mean 4,957/ml, range 1,589-15,527/ ml）(p=0.057）（図 1).

2) 結核組織の免疫染色 21 人の結核患者から得られた結核組織の H-E 染色では，乾酪壊死とラングハンス巨細胞を 伴った類上皮肉芽腫とその周囲に単核球が集簇 する典型的な結核の組織構造が認められた（図 2A).

結核組織の免疫染色は, 21 名のパラフィン包 埋の切片と 4 名の凍結切片 (結核性リンパ節炎) で行なった，成熟 DC に発現する fascin が陽性 の細胞が類上皮細胞周囲のリンパ球領域を中心 に多数認められた（図 2B）。fascin 陽性細胞は,
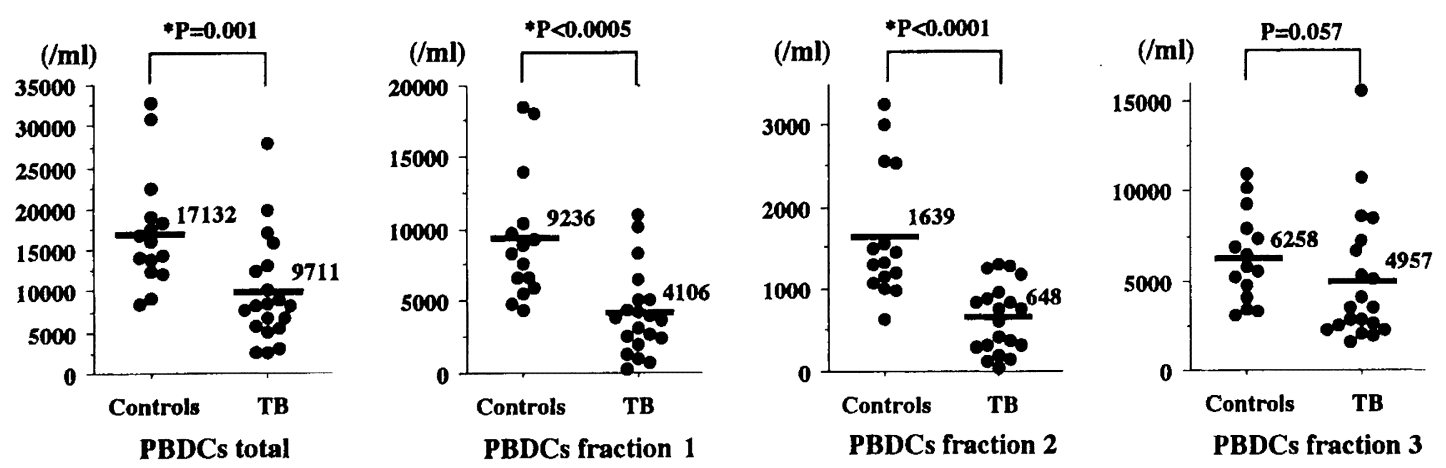

図 1 末梢血 DC における細胞数の検討

結核患者では末梢血 DC が $9711 / \mathrm{ml}$ と健常者の $17132 / \mathrm{ml}$ に比較して有意に減少している. 亜群解析の結果，こ の減少はミエロイド系 DCである Fraction 1 及び Fraction 2 DC の減少に起因している. Fraction 3 DC は若干の 減少を認めたが有意な低下ではなかった。 

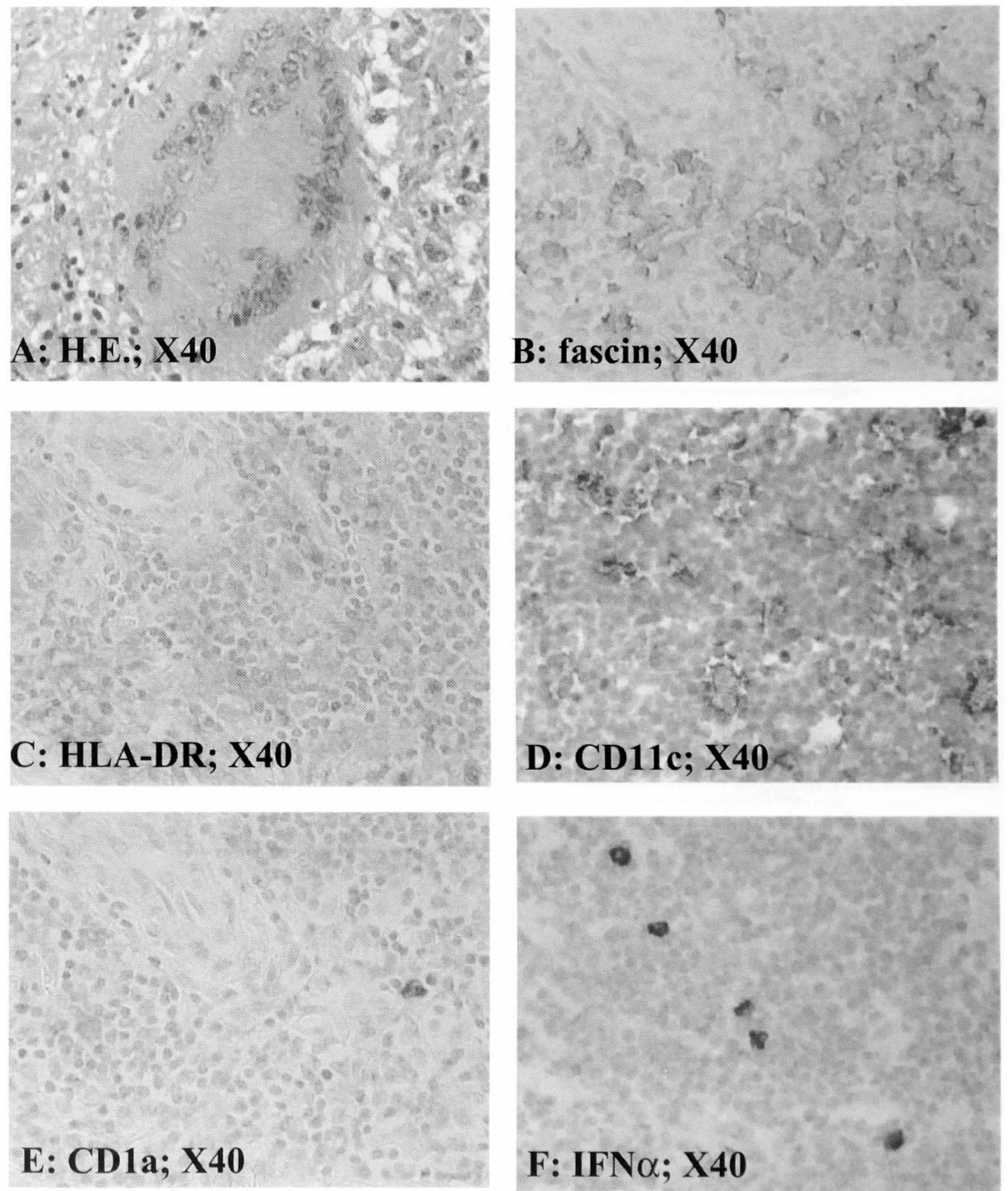

図 2 結核組織の H-E 染色と免疫染色 A：H-E 染色，B：fascin， C : HLA-DR, D : CD11c, E : CD1a, F : IFN $\alpha$,

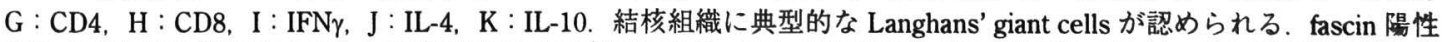
細胞を類上皮細胞周囲のリンパ球領域を中心に多数認める. B との連続切片で同じ場所に HLA-DR 陽性細胞が存在す る. fascin 陽性細胞, HLA-DR 陽性細胞はともに樹状突起を有している. CD11c の染色では，類上皮細胞周囲リンパ 球領域にCD11c 陽性細胞の存在が確認され, fascin 陽性細胞, HLA-DR 陽性細胞と同様に樹状突起を持ち、また同じ 頻度で認められる. B と C との連続切片での CD1a 染色の結果, fascin および HLA-DR 陽性細胞は CD1a が院性であ る. IFN $\alpha$ の染色では，低頻度ながら類上皮細胞周囲リンパ球領域において浸潤を認める。類上皮細胞周囲のリンパ 球領域では CD4 陽性細胞と CD8 陽性細胞が多数認められる.サイトカインの免疫染色では CD4 陽性, CD8 陽性 T リ ンパ球の多くは IFN $\gamma$ を産生しているが, IL-4 と IL-10 産生細胞は少数である. 

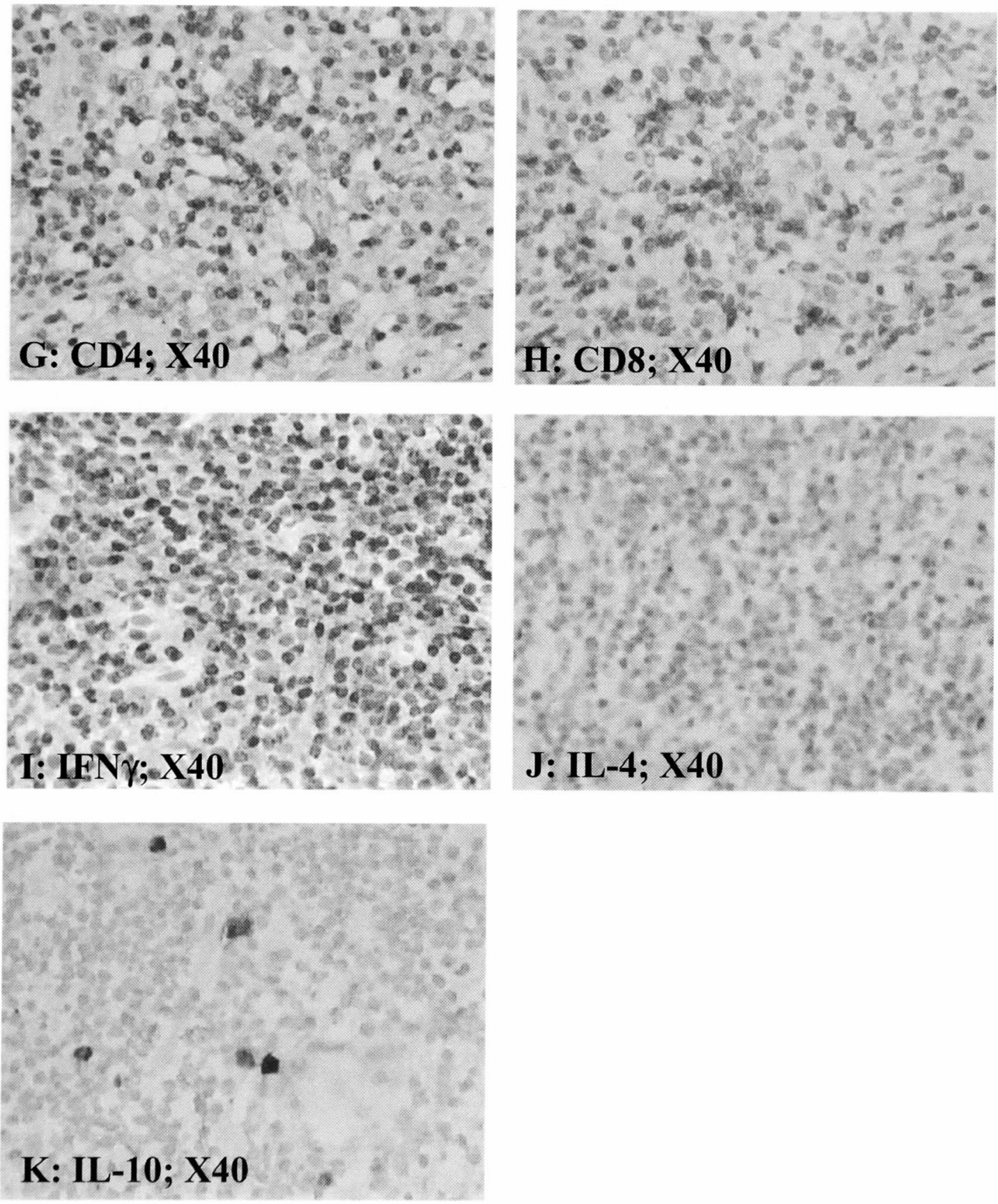

図 2（つづき）

連続切片にて HLA-DRが陽性であった(図 2C). これら fascin 陽性細胞が EBV 感染 B 細胞では ないことを証明するために EBNA-2 と LMP-1に
対する抗体で染色したが陽性細胞は認めなかっ た (data not shown). fascin 陽性細胞と CD11c 陽性細胞は相対的に発現頻度が同程度であった 

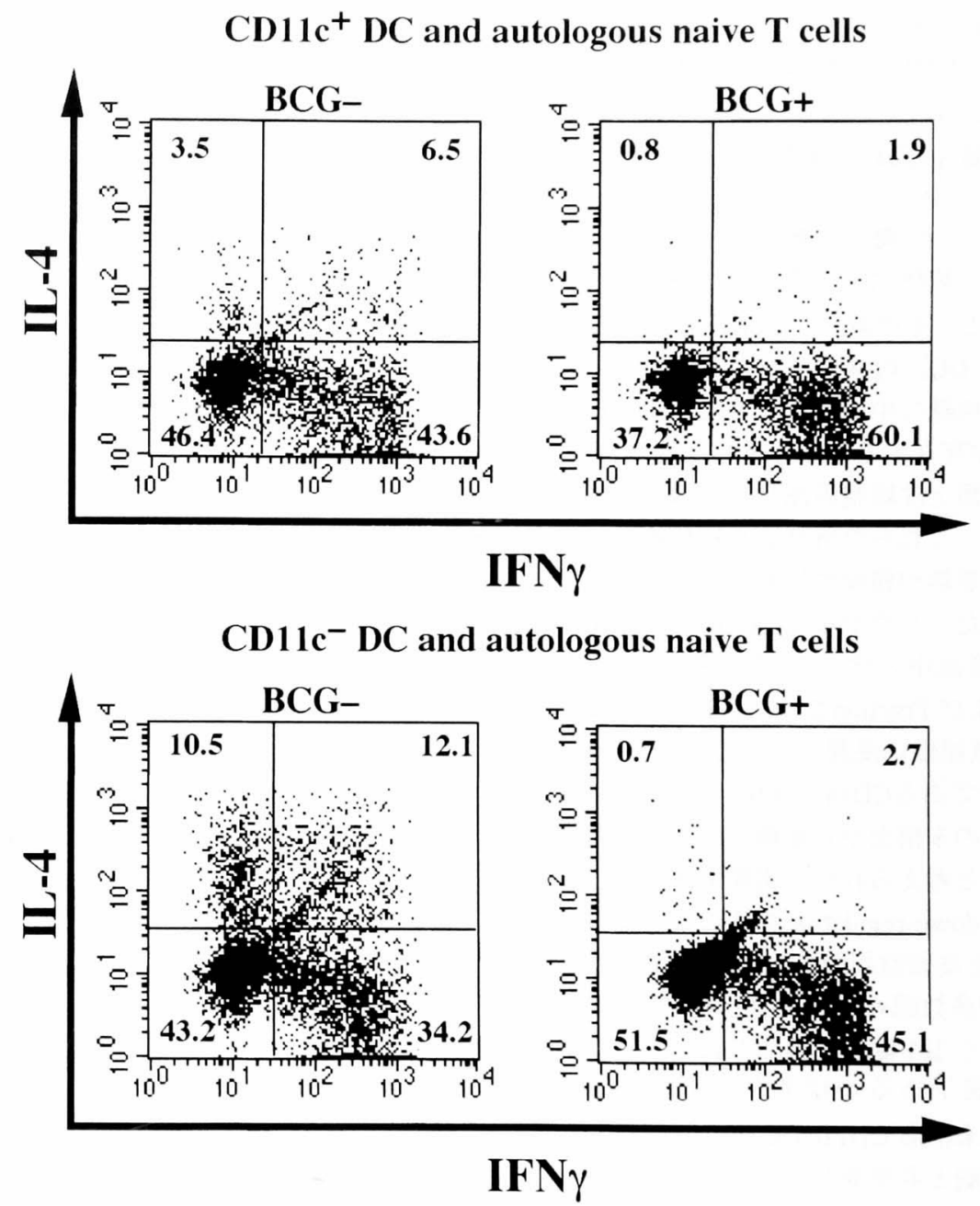

図 $3 \mathrm{CD}^{2} 1 \mathrm{c}^{+} \mathrm{DC}$ によるナイーブ細胞の Th1 偏向

CD11c陽性DC, CD11c陰性DCはともにBCG非存在下に比べBCGを加えた共培養系においてより強くTh1が誘導 された.

ことから fascin 陽性 /HLA-DR 陽性細胞の多く は, CD11c 陽性であることが判明した (図 2D). これら fascin 陽性細胞, HLA-DR 陽性細胞, CD11c 陽性細胞は全て樹状突起を有していた (図 2B，C，D）. しかし，fascin 陽性 /HLA-DR 陽性細胞は, 連続切片での染色で CD1a が陰性 であった（図 2E).

また少数ではあるが類上皮細胞周囲リンパ球 領域において IFN $\alpha$ 陽性細胞が認められ。 Fraction 3 DC の存在が確認された（図 2F).
一方類上皮細胞周囲リンパ球領域ではCD4あ るいは CD8 陽性細胞が多数認められた (図 2G, H).これらリンパ球の多くは IFN $\gamma$ 産生細胞で (図 2I)，IL-4 あるいは IL-10 陽性細胞は少数で あった（図 2J，K).

3） $\mathrm{CD} 11 \mathrm{c}^{+} \mathrm{DC}$ による naive T cells の Th1 偏向 BCG 存在下あるいは非存在下で. ミエロイド 系 DCである $\mathrm{CD} 11 \mathrm{c}^{+} \mathrm{DC}$ とリンバ球系 DCであ る CD11c-DCのそれぞれを autologous naive Th と共培養することにより，DCの Thl あるいは 
Th2 の誘導能を検討した.

その結果, $\mathrm{CD} 11 \mathrm{c}^{+} \mathrm{DC}, \mathrm{CD} 11 \mathrm{c}^{-} \mathrm{DC}$ はともに BCG 非存在下に比べ BCG を加えた共培養系に おいてより強くTh1 を誘導した（図 3).

\section{考察}

今回我々は，結核では循環血中の DC 総数が減 少していること, その減少が Fraction 1+2 DC (= ミエロイド系 DC）の減少に起因していることを 示した，結核組織の中に fascin ${ }^{+} / \mathrm{HLA}^{-\mathrm{DR}^{+} / \mathrm{CD} 1 \mathrm{a} /}$ $\mathrm{CD}_{11 \mathrm{c}}{ }^{+}$細胞が存在することも示した. また IPC も 低頻度ながら類上皮細胞周囲リンパ球領において 浸潤していた。これらの所見より結核組織には末 梢血から DC 亜群が積極的に動員されていること が明かとなった。したがって fascin 陽性 DC は, 大部分が末梢血中のミエロイド系 DC である Fraction 1 および Fraction 2 DC 由来であることが 判明した. 結核組織に浸潤しているDCが Fraction $1 \mathrm{DC}$ markerであるCD1aを発現していないのは, Fraction $1 \mathrm{DC}$ の末梢血から組織への移動に伴う成 熟によるものと考えられた。実際 CD1a は DC の 成熟とともにdown-regulationすることが知られて いる ${ }^{14,15)}$. 類上皮細胞周囲リンパ球領域では IFN 産生 T 細胞が多数認められ, 結核局所での Th1 偏 向のみではなく Tc1 偏向も確認された.

BCG 存在下あるいは非存在下で，末梢血 $\mathrm{CD} 11 \mathrm{c}^{+} \mathrm{DC}$ と末梢血 CD11c-DC のそれぞれを自己 の naive Th 細胞と共培盖した in vitro の実験から, 結核感染においてはミエロイド系 DC とリンパ球 系 DC はともに，Th1 への偏向性を示すことが明 らかとなった。

以上の結果より, 我々は結核感染における以下

の 'DC trafficking model' を提唱している.

すなわち結核感染では danger signalによって末 梢血の DC が組織へ動員される．その大部分がミ エロイド系 DC であるが，わずかながらリンパ球 系 DC も浸潤し，IFN $\alpha$ を産生する，感染局所で DCは, 結核菌の刺激により成熟活性化され所属り ンパ節に移動し,ささらにナイーブ T 細胞を Th1 と Tc1にシフトし,そのリンパ球が tubercleに戻り結 核免疫を誘導すると考えられた。

この model から, 結核感染において DC は結核 免疫を導く重要な細胞であることが示唆される。

\section{文献}

1) Kochi, A.: The global tuberculosis situation and the new control strategy of the World Health Organization. Tubercle, 72: 1-6, 1991.

2) Kaufmann, S. H. and Ladel, C. H.: Role of T cell subsets in immunity against intracellular bacteria: experimental infections of knock-out mice with Listeria monocytogenes and Mycobacterium bovis BCG. Immunobiology, 191: 509-519, 1994.

3) Stenger, S., Mazzaccaro, R. J., Uyemura, K., Cho, S., Barnes, P. F., Rosat, J. P., Sette, A., Brenner, M. B., Porcelli, S. A., Bloom, B. R. and Modlin, R. L.: Differential effects of cytolytic $T$ cell subsets on intracellular infection. Science, 276: 1684-1687, 1997.

4) Rissoan, M. C., Soumelis, V., Kadowaki, N., Grouard, G., Briere, F., de Waal Malefyt, R. and Liu, Y. J.: Reciprocal control of $T$ helper cell and dendritic cell differentiation. Science, 283: 1183-1186, 1999.

5) Ito, T., Amakawa, R., Inaba, M., Ikehara, S., Inaba, K. and Fukuhara, S.: Differential regulation of human blood dendritic cell subsets by IFNs. J Immunol, 166: 2961-2969, 2001.

6) Cella, M., Facchetti, F., Lanzavecchia, A. and Colonna, M.: Plasmacytoid dendritic cells activated by influenza virus and CD40L drive a potent TH1 polarization. Nat Immunol, 1: 305-310, 2000.

7) Langenkamp, A., Messi, M., Lanzavecchia, A. and Sallusto, F.: Kinetics of dendritic cell activation: impact on priming of TH1, TH2 and nonpolarized T cells. Nat Immunol, 1: 311-316, 2000.

8) Henderson, R. A., Watkins, S. C. and Flynn, J. L.: Activation of human dendritic cells following infection with Mycobacterium tuberculosis. J Immunol, 159: 635643, 1997.

9) Demangel, C., Bean, A. G., Martin, E., Feng, C. G., Kamath, A. T. and Britton, W. J.: Protection against aerosol Mycobacterium tuberculosis infection using Mycobacterium bovis Bacillus Calmette Guerininfected dendritic cells. Eur J Immunol, 29: 19721979, 1999.

10) Fortsch, D., Rollinghoff, M. and Stenger, S.: IL-10 converts human dendritic cells into macrophage-like cells with increased antibacterial activity against virulent Mycobacterium tuberculosis. J Immunol, 165: 978$987,2000$.

11) Ito, T., Inaba, M., Inaba, K., Toki, J., Sogo, S., Iguchi, T., Adachi, Y., Yamaguchi, K., Amakawa, R., Valladeau, J., Saeland, S., Fukuhara, S. and Ikehara, S.: A CD1a+/ CD11c+ subset of human blood dendritic cells is a direct precursor of Langerhans cells. J Immunol, 163: 1409-1419, 1999.

12) Siegal, F. P., Kadowaki, N., Shodell, M., FitzgeraldBocarsly, P. A., Shah, K., Ho, S., Antonenko, S. and Liu, 
Y. J.: The nature of the principal type 1 interferon-producing cells in human blood. Science, 284: 1835-1837, 1999.

13) Ozaki, Y., Amakawa, R., Ito, T., Iwai, H., Tajima, K., Uehira, K., Kagawa, H., Uemura, Y., Yamashita, T. and Fukuhara, S.: Alteration of peripheral blood dendritic cells in patients with primary Sjogren's syndrome. Arthritis Rheum, 44: 419-431, 2001.
14) Schuler, G. and Steinman, R. M.: Murine epidermal Langerhans cells mature into potent immunostimulatory dendritic cells in vitro. J Exp Med, 161: 526-546, 1985.

15) Stenger, S., Niazi, K. R. and Modlin, R. L.: Down-regulation of $\mathrm{CD} 1$ on antigen-presenting cells by infection with Mycobacterium tuberculosis. J Immunol, 161: 3582-3588, 1998. 